\title{
Ovarian inhibin content and sensitivity to inhibin in Booroola and control strain Merino ewes
}

\author{
L. J. Cummins*, T. O’Shea, B. M. Bindon†, V. W. K. Lee $\ddagger$ and \\ J. K. Findlay $\ddagger$ \\ Physiology Department, University of New England, Armidale, New South Wales 2351; †CSIRO, \\ Division of Animal Production, Armidale, New South Wales 2350; and $\ddagger$ Medical Research Centre, \\ Prince Henry's Hospital, Melbourne, Victoria 3004, Australia
}

\begin{abstract}
Summary. The inhibin content of ovaries collected from highly fecund Booroola Merino ewes was only one third that of control Merino ewes. Ovariectomized ewes of both strains were treated with charcoal-treated ovine follicular fluid for 2 days. A dosedependent effect on plasma FSH was observed: maximum FSH suppression was observed on the day after the last injection of follicular fluid. Ewes receiving the highest dose of follicular fluid (total dose 72000 units of inhibin) had FSH levels depressed to only $8 \%$ of pre-treatment levels. Booroola ewes showed FSH suppression 1 day earlier than control ewes but otherwise the responses of the two strains to follicular fluid were similar. Plasma LH levels were only slightly depressed with the highest dose of follicular fluid. These results suggest that the feedback relationship of inhibin and FSH in Booroola ewes may be set differently from that in control ewes and this may contribute to the difference in ovulation rate between ewes of the two genotypes.
\end{abstract}

\section{Introduction}

The Booroola Merino (Turner, 1978) is one of the world's most prolific sheep breeds and is characterized by having much higher ovulation rates than normal Merinos (Bindon, Ch'ang \& Turner, 1971). Individual Booroola ewes have recently been recorded with up to 10 and 11 ovulations, the highest natural ovulation rate yet recorded for sheep (Bindon \& Piper, 1982). It is now known that the genetic basis of the Booroola lies in a single gene with a major effect on ovulation (Piper \& Bindon, 1982). The physiological basis of this genetic phenomenon is poorly understood although mechanisms controlling growth and atresia of follicles are thought to be involved.

Follicle-stimulating hormone (FSH) is required for the continued development of pre-antral and antral follicles (Peters \& NcNatty, 1980). The widespread use of exogenous gonadotrophins with FSH-like activity to stimulate additional ovulations (see Betteridge, 1981), and the demonstration that plasma FSH levels are elevated before ovulation in groups of sheep with increased ovulation rates induced by supplementation of the diet with lupins (Brien, Baxter, Findlay \& Cumming, 1976; Davis, Brien, Findlay \& Cumming, 1981; Knight, Payne \& Peterson, 1981) suggest that the short-term regulation of FSH may be important in the final control of ovulation rate. This possibility is further supported by the observation that compensatory ovulation after unilateral ovariectomy is associated with a transient increase in FSH secretion (Findlay \& Cumming, 1977).

* Present address: Pastoral Research Institute, Hamilton, Victoria 3300, Australia. 
The regulation of FSH concentration is partly dependent on ovarian production of inhibin (de Jong, 1979). Goodman, Pickover \& Karsch (1981) have concluded that an ovarian factor other than oestradiol and progesterone must contribute to the suppression of FSH during the ovine oestrous cycle. In female rats there is evidence that FSH secretion and ovarian follicular development involve an inhibin feedback system (Welschen, Hermans \& de Jong, 1980). Furthermore, Lee, McMaster, Quigg, Findlay \& Leversha (1981) have shown that PMSG, which stimulates follicular development in the rat, will increase ovarian and circulatory levels of inhibin and depress endogenous FSH levels.

The purpose of the present study was to examine the possibility that differences in the production and/or effects of ovarian inhibin may help to explain the genetic differences in ovulation rate between Booroola and control strain Merino ewes.

\section{Materials and Methods}

\section{Experiment 1}

Ovaries were collected from individually identified ewes from flocks of the Booroola type and a random bred control flock of Merinos slaughtered at a local abattoir in August, i.e. towards the end of the breeding season for normal Merino ewes in this environment, although Booroola ewes are known to have a longer breeding season than control Merinos (Bindon \& Piper, 1982). Ovaries were selected as being from the mid-luteal phase of the oestrous cycle on the basis of gross morphology of the corpora lutea and stored at $-15^{\circ} \mathrm{C}$ until assayed. The ovaries were weighed and the number of corpora lutea counted. For each genotype, 5 pairs of ovaries were selected from young ewes (2-3 years old) and 5 pairs of ovaries were selected from old ewes (6 years old).

Ovarian cytosol fractions were prepared by homogenizing each pair of ovaries (with corpora lutea still present) from each ewe in $20 \mathrm{ml}$ ice-cold saline $(0 \cdot 154 \mathrm{M}-\mathrm{NaCl})$ followed by centrifugation at $105000 \mathrm{~g}$ for $1 \mathrm{~h}$ at $4^{\circ} \mathrm{C}$. From each ovarian cytosol preparation a $0.1 \mathrm{ml}$ sample was extracted with $0.9 \mathrm{ml}$ of $1 \mathrm{mg} / \mathrm{ml}$ dextran-coated charcoal $(1: 10 \mathrm{w} / \mathrm{w})$ at $23^{\circ} \mathrm{C}$ for $10 \mathrm{~min}$ followed by a $30 \mathrm{~min}$ incubation at $4^{\circ} \mathrm{C}$ and centrifugation at $7000 \mathrm{~g}$ for $2 \mathrm{~min}$ (Lee et al., 1981). Each supernatant sample was then assayed for inhibin activity at two dilutions $(1: 6$ and $1: 30)$ in triplicate using the in-vitro pituitary cell culture system described by Scott, Burger \& Quigg (1980). At this concentration in the bioassay the follicular fluid did not significantly suppress the LH content of the pituitary cells. All samples were assayed in a single assay and the inhibin activity of the unknown samples was assessed by regression analysis and parallel line assay statistics (Borth, 1976). The index of preci$\operatorname{sion}(\lambda)$ of the assay was $0 \cdot 15$. The inhibin reference standard was an ovine testicular lymph protein preparation with an arbitrary potency of $1 \mathrm{U} / \mathrm{mg}$ (Eddie, Baker, Higginson \& Hudson, 1979). Mean ovarian inhibin values for the two genotypes were compared using Student's $t$ test.

\section{Experiment 2}

The aim of this experiment was to examine the effect of steroid-free ovine follicular fluid, a rich source of inhibin activity (Tsonis et al., 1981) on plasma FSH and LH concentrations in these 2 strains of sheep.

Booroola and control Merino ewes ( 2 or 3 years old) were ovariectomized during July. At the end of October (non-breeding season) ewes were randomly allocated to 4 treatment groups. The treatments consisted of the subcutaneous injection of $2 \mathrm{ml}$ charcoal-treated ewe plasma (i.e. control) or $0.5,1$ or $2 \mathrm{ml}$ of charcoal-treated ovine follicular fluid at $09: 00$ and $17: 00 \mathrm{~h}$ on Days 2 and 3 of the blood sampling period. There were 6 ewes of each genotype allocated to each treatment. Starting at 10:00 h, blood samples were taken from each ewe by jugular venepuncture at hourly intervals for $6 \mathrm{~h}$ on each consecutive day for 6 days. Plasma was collected and equal volumes pooled to form a single composite sample for each ewe each day and stored at $-15^{\circ} \mathrm{C}$ until assayed for LH and FSH. 
The follicular fluid for injection was aspirated from all visible follicles of the ovaries of sheep (mainly lambs) being slaughtered at a local abattoir during late winter and stored at $-15^{\circ} \mathrm{C}$ until required. Plasma was obtained from jugular vein blood of intact luteal-phase ewes. Before use, steroids were removed by adding $50 \mathrm{mg}$ dextran-coated activated charcoal to each $\mathrm{ml}$ follicular fluid or ewe plasma and shaking intermittently for $30 \mathrm{~min}$ at room temperature $\left(\simeq 23^{\circ} \mathrm{C}\right)$. The charcoal was then removed by centrifugation at $18000 \mathrm{~g}$ for $1 \mathrm{~h}$ at $4^{\circ} \mathrm{C}$ and filtration (Whatman, No. 41 paper) of the supernatant. We have demonstrated that these procedures will render follicular fluid essentially steroid-free (O’Shea, Cummins, Lutjen \& Bindon, 1980). The follicular fluid used in this experiment had an inhibin potency of $9000 \mathrm{U} / \mathrm{ml}(95 \%$ confidence limits $4600-15400)$.

The LH measurements were carried out on duplicate $300 \mu \mathrm{l}$ plasma samples using a modification of the solid-phase radioimmunoassay described by Goding et al. (1969). The rabbit anti-ovine LH antiserum, the iodinated LH antiserum, the iodinated LH tracer and details of the assay sensitivity, validation and specificity have been described by Gidley-Baird \& Bindon (1976). The sensitivity of the method was $0.6 \mathrm{ng} / \mathrm{ml}$ plasma using NIH-LH-S16 as the standard. The withinassay coefficient of variation (CV) for reference samples was $9 \%$ for ovine plasma samples containing $5 \mathrm{ng} / \mathrm{ml}$ and $15 \%$ for samples containing $57 \mathrm{ng} / \mathrm{ml}$.

The FSH measurements were carried out on duplicate $50 \mu \mathrm{l}$ samples of plasma using the doubleantibody radioimmunoassay described by Bremner, Findlay, Lee, de Kretser \& Cumming (1980). The sensitivity of the assay was $18 \mathrm{ng} / \mathrm{ml}$ using NIH-FSH-S6 as standard, and the within-assay CV was $<10 \%$ for samples in the range $130-800 \mathrm{ng} / \mathrm{ml}$ and $<20 \%$ for samples in the range $42-2500$ $\mathrm{ng} / \mathrm{ml}$. For both LH and FSH all samples were analysed in one assay.

For statistical analysis, plasma gonadotrophin levels for each ewe for Days 2-6 were transformed to a percentage of the value on Day 1 (i.e. before treatment). For FSH data, a minimum value of $5 \%$ was used for FSH values which were at or below the limit of assay sensitivity. Analysis of variance on log-transformed data was carried out on a within-day basis to examine the effects of dose of follicular fluid and strain of ewe.

\section{Experiment 1}

\section{Results}

As shown in Table 1 the inhibin content of the ovaries of Booroola ewes was only $33 \%(P<$ $0.001)$ of that observed in control ewes despite the fact that the Booroola ovulation rate was 2.33 times that of the controls. Age of ewe was not related to ovarian inhibin content. Within the control ewes inhibin levels were significantly correlated $(r=0.81)$ with ovarian weight and this correlation was mainly due to the higher inhibin content in the ovaries of the 2 ewes in this group with twin ovulations. There was no evidence of such a correlation $(r=0.03)$ within the Booroola ewes. The correlation between the number of corpora lutea and ovarian inhibin content $(r=-0.29)$ in the Booroola ewes was also not significant.

Table 1. A comparison of ovarian inhibin content, ovarian weight and ovulation rate in 10 Booroola and 10 control Merino ewes (means for single ovaries \pm s.e.m.)

\begin{tabular}{lccc}
\hline & \multicolumn{2}{c}{ Strain of ewe } & \\
\cline { 2 - 3 } & Control & Booroola & Significance \\
\hline Ovarian weight $(\mathrm{g})$ & $1.23 \pm 0.12$ & $1 \cdot 21 \pm 0.09$ & n.s. \\
No. of CL/ovary & $0.6 \pm 0.1$ & $1.4 \pm 0.3$ & $P<0.01$ \\
Inhibin content (Units/ovary) & $1230 \pm 130$ & $400 \pm 60$ & $P<0.001$ \\
\hline
\end{tabular}


Table 2. Mean \pm s.e.m. plasma gonadotrophin concentrations in 24 Booroola and 24 control ovariectomized ewes before treatment with follicular fluid (i.e. Day 1 of Exp. 2)

\begin{tabular}{lccc}
\hline Hormone & $\begin{array}{c}\text { Control } \\
\text { ewes }\end{array}$ & $\begin{array}{c}\text { Booroola } \\
\text { ewes }\end{array}$ & Significance \\
\hline LH $(\mathrm{ng} / \mathrm{ml})$ & $15 \pm 1$ & $11 \pm 1$ & $P<0.05$ \\
FSH $(\mathrm{ng} / \mathrm{ml})$ & $380 \pm 30$ & $330 \pm 30$ & n.s. \\
\hline
\end{tabular}

\section{Experiment 2}

Ovariectomized Booroola ewes had slightly lower $(P<0.05)$ plasma concentrations of LH than did the control ovarietomized ewes on the first day of the experiment, but FSH concentration did not differ between the genotypes (Table 2).

The effect of follicular fluid on plasma FSH and LH levels is illustrated in Text-fig. 1. On Day 2 there was a significant strain difference $(P<0.01)$ in FSH concentration, while the dose and dose $\times$ strain interactions approached significance $(P<0 \cdot 1)$. This effect was due to the fact that the first injection of follicular fluid had no detectable influence on FSH concentration in control ewes, whereas in Booroola ewes all 3 dose levels of follicular fluid caused a similar reduction (of the order of $25 \%$ ) in FSH (Text figs la \& 1b). FSH concentrations were therefore more sensitive to inhibin in Booroola ewes.
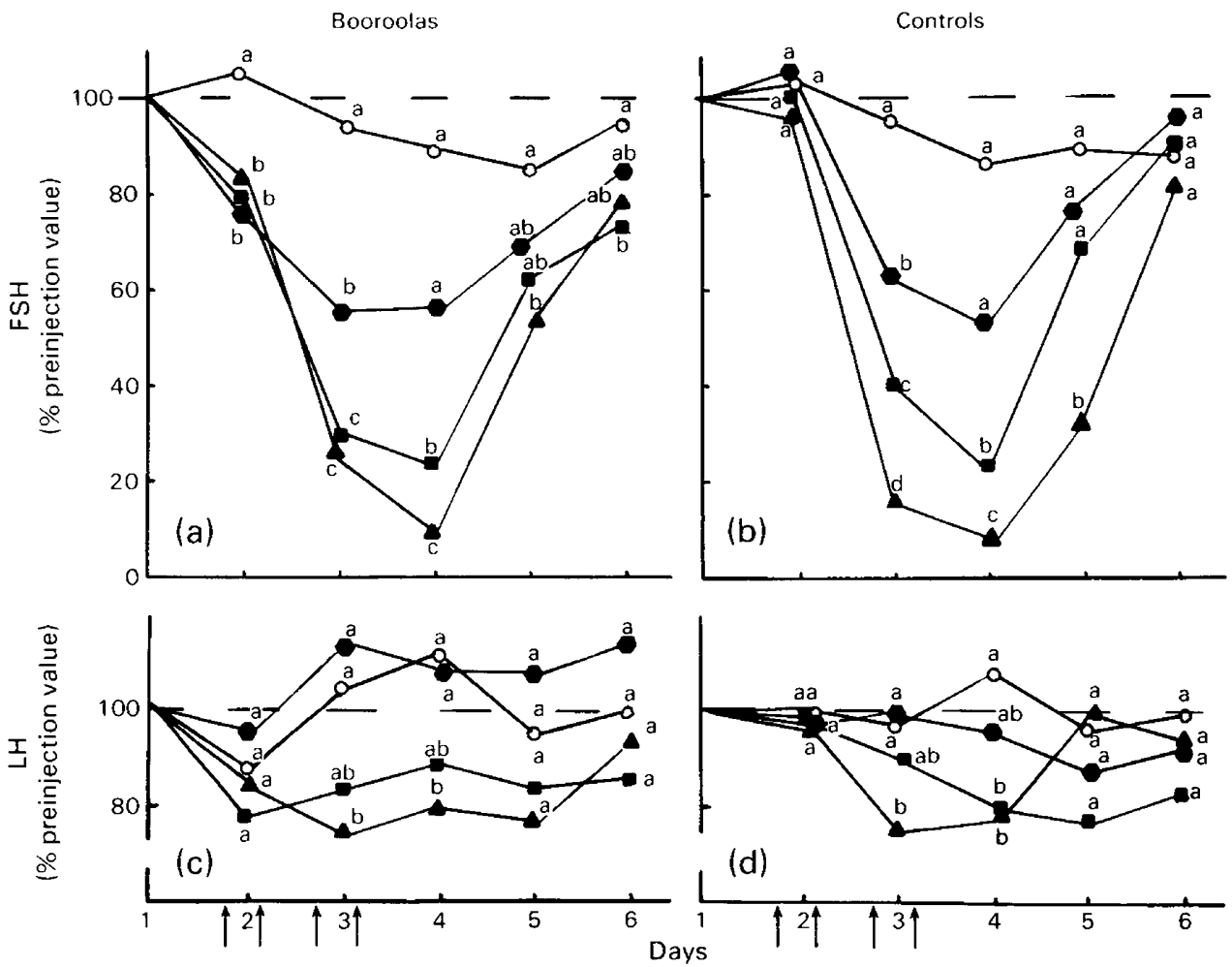

(d)

Text-fig. 1. Changes in plasma gonadotrophin concentrations in ovariectomized Booroola $(a, c)$ and control (b, d) ewes injected (arrows) with charcoal-treated plasma or follicular fluid at $09: 00$ and 17:00 h on Days 2 and 3. Within days, values with different superscripts differ significantly $(P<0.05)$. Dose of follicular fluid: $0(0), 0.5(0), 1(\square)$ or $2(\Delta) \mathrm{ml}$. 
On Day 3 both genotypes of ewe responded to follicular fluid injections with dose-dependent reductions in FSH concentration $(P<0.001)$. However, there was a significant strain $\times$ dose interaction $(P<0.05)$ due to the Booroolas showing slightly greater responses to the lower doses and the controls a greater response to the highest dose of follicular fluid.

On Day 4, the day after the final injection of follicular fluid, ewes of both genotypes responded similarly with a dose-dependent reduction in FSH concentration. Minimal FSH values were observed on Day 4. Ewes that had received the highest doses of follicular fluid (equivalent to a dose of $36 \mathrm{kU}$ inhibin per day for 2 days) had FSH concentrations suppressed to only $8 \%$ of pretreatment values.

Recovery of FSH levels had begun on Day 5 with only those ewes receiving the highest dose of follicular fluid still differing from the groups which had received plasma, while on Day 6 there were no significant effects of treatment.

The effects of follicular fluid on plasma LH concentration were much less than on FSH, with ewes of both genotypes responding similarly. LH concentrations were not significantly altered by follicular fluid on Days 2, 5 and 6. Suppression of $\mathrm{LH}$ concentration to $75 \%$ of pre-treatment values by the highest dose of follicular fluid was observed on Day 3. On Day 4, the dose effects on LH were again significant $(P<0.05)$ with both the 1 and $2 \mathrm{ml}$ treatments differing from the plasma-treated group.

\section{Discussion}

This study demonstrates that treatment of ovariectomized ewes with essentially steroid-free ovine follicular fluid, a rich source of inhibin activity (Tsonis et al., 1981), had dose- and time-dependent effects on peripheral FSH concentrations in Booroola and control Merino ewes. This suppression of FSH in preference to $\mathrm{LH}$ in ovariectomized ewes is similar to the responses of other species to injections of homologous and heterologous follicular fluid (de Jong \& Sharpe, 1976; Marder, Channing \& Schwartz, 1977; Welschen, Hermans, Dullaart \& de Jong, 1977; Bronson \& Channing, 1978; Miller, Wesson \& Ginther, 1981) although not all these studies examined dose and time effects. The suppression of plasma FSH appeared to be greater in our studies than that observed in most other experimental situations. This might be partly due to a greater sensitivity to inhibin activity in females than males. In sheep, for example, inhibin of testicular origin given to wethers by intravenous infusion for $24 \mathrm{~h}$ resulted in a dose-dependent suppression of FSH with a maximal suppression of FSH of only about $50 \%$ with a total dose of $40 \mathrm{kU}$ inhibin (Eddie et al., 1980). Hermans, van Leeuwen, Debets \& de Jong (1980) reported that follicular fluid caused less suppression of FSH in castrated adult male than female rats. The route of administration may also be important. The subcutaneous route of administration as used in this experiment leads to more profound inhibitory effects on ovulation in intact ewes than does intravenous injection of similar doses (O'Shea et al., 1980). The doses of follicular fluid were similar to those given to intact ewes around the time of luteolysis and which caused marked suppression of ovulation (Cummins, Bindon, O'Shea \& Piper, 1980; O'Shea et al., 1980).

In the normal physiological regulation of gonadotrophin secretion in the intact ewe, ovarian steroids and inhibin appear to be required (Goodman et al., 1981). There is a suggestion that inhibin may act in an additive manner with steroids to suppress FSH in ovariectomized mice (Bronson \& Channing, 1978) and mares (Miller et al., 1981), while it may by synergistic in male rats (Hopkinson, Fritze, Chari, Sturm \& Hirschhäuser, 1977; Peek \& Watkins, 1980).

Although the more fecund Booroola ewes were more sensitive to injections of follicular fluid (e.g. FSH response on Day 2), their ovaries contained only one third of the inhibin content of ovaries of control ewes. Inhibin is produced by granulosa cells within the ovarian follicle (Erickson \& Hsueh, 1978; Sato, Miyamoto, Ishibashi \& Iritani, 1978) and the inhibin content of sheep follicles is related to follicular size (Tsonis et al., 1981) and hence granulosa cell volume (Tsonis \& 
Findlay, 1981). Antral follicles in Booroola ewes have a lower volume of granulosa cells than antral follicles of the same diameter from control ewes (R. J. Scaramuzzi \& K. E. Turnbull, personal communication). This would probably account for the lower inhibin content in Booroola ovaries. Alternatively, the rate of release of inhibin by follicles may be higher in Booroola than in control ewes.

The proposed genetic basis of ovulation rate in the Booroola flock implies three possible genotypes, i.e. homozygous carriers, heterozygotes or non-carriers. Ewes with at least one copy of the Booroola gene are likely to have an ovulation rate of 3 or more (Davis, Montgomery, Allison, Kelly \& Bray, 1981; Piper \& Bindon, 1982). Our current estimate of the frequency of the Booroola gene in the Booroola flock is of the order of $60 \%$. Based on the history of ovulation rates of the ewes in Exp. 1, we consider that a minimum of $70 \%$ of Booroola ewes in fact carried at least one copy of the Booroola gene. Within the Booroola ewes there was no correlation between ovulation rate and ovarian inhibin content. The correlation between ovarian inhibin content and ovarian weight in the control ewes is probably largely due to the contribution of follicular development to ovarian weight. No explanation is offered for the lower LH levels observed in ovariectomized Booroola ewes (Table 2). Further observations on the pulsatile nature of pituitary $\mathrm{LH}$ secretion would be required to clarify these observations.

Our results suggest that the feedback relationship of inhibin and FSH in Booroola ewes may be set differently from that in control ewes. If FSH is a determinant of follicular growth and ovulation rate, our results on ovarian inhibin content indicate that secretion and hence plasma concentrations of FSH in intact Booroola ewes might be higher than in control ewes. This is the case in prepubertal ewes (Findlay \& Bindon, 1976). Data are not yet available for mature ewes, but some observations of plasma FSH concentrations (L. J. Cummins, B. M. Bindon \& J. K. Findlay unpublished observations) based on single ( 26 ewes per genotype: Booroola $=105 \pm 10$ and control $=90 \pm 9$ $\mathrm{ng} / \mathrm{ml}$ ) or double samples (10 ewes per genotype: Booroola $=113 \pm 8$ and control $97 \pm 4 \mathrm{ng} / \mathrm{ml}$ ) collected during the mid-luteal phase of the oestrous cycle in intact ewes indicate that this possibility should be further explored. It is also possible that the effects of lower inhibin levels in the Booroola may be negated by their increased sensitivity, providing that increased sensitivity also occurs in intact ewes. It is likely that only small differences in plasma FSH concentrations at critical times of follicular development may be all that is required to enhance the ovulation rate. Support for this suggestion is provided by studies relating FSH and ovulation rate in genetically different strains of ewe (Cahill et al., 1981) and unilaterally ovariectomized ewes (Findlay \& Cumming, 1977).

These studies indicate that the inhibin/FSH feedback loop is likely to be important in regulating gonadotrophin secretion and hence directly or indirectly play a role in regulating ovulation rate in these genetically diverse strains of ewe.

We thank T. Gill, L. Leversha, J. McMaster, E. Quigg, M. Cheers, R. Nethery, Y. Curtis, G. Chaffey and J. Reid for technical assistance; NIH and Dr H. Papkoff for pituitary hormones; and the Australian Meat Research Committee and National Health and Medical Research Council of Australia for financial support.

\section{References}

Betteridge, K.J. (1981) An historical look at embryo transfer. J. Reprod. Fert. 62, 1-13.

Bindon, B.M. \& Piper, L.R. (1982) Physiological characteristics of high fecundity sheep and cattle. Proc. Wld Cong. Sheep, Cattle Breed. (in press).

Bindon, B.M., Ch'ang, T.S. \& Turner, H.N. (1971) Ovarian response to gonadotrophin by Merino ewes selected for fecundity. Aust. J. agric. Res. 22, 809-820.
Borth, R. (1976) Statistics of parallel-line assay. In Methods of Hormone Analysis, p. 500. Eds H. Breuer, D. Hamel \& H. L. Kruskemper. Thieme Verlag, Stuttgart.

Bremner, W.J., Findlay, J.K., Lee, V.W.K., de Kretser, D.M. \& Cumming, I.A. (1980) Feedback effects of the testis on pituitary responsiveness to LH-RH infusions in the ram. Endocrinology 106, 329-336. 
Brien, F.D., Baxter, R.W., Findlay, J.K. \& Cumming, I.A. (1976) Effect of lupin grain supplementation on ovulation rate and plasma follicle stimulating hormone (FSH) concentration in maiden and mature Merino ewes. Proc. Aust. Soc. Anim. Prod. 11, 237-240.

Bronson, F.H. \& Channing, C.P. (1978) Suppression of serum follicle stimulating hormone by follicular fluid in the maximally estrogenized ovariectomized mouse. Endocrinology 103, 1894-1898.

Cahill, L.P., Saumande, J., Ravault, J.P., Blanc, M., Thimonier, J., Mariana, J.C. \& Mauléon, P. (1981) Hormonal and follicular relationships in ewes of high and low ovulation rates. J. Reprod. Fert. 62, 141-150.

Cummins, L.J., Bindon, B.M., O'Shea, T. \& Piper, L.R. (1980) Effects of ovine follicular fluid given during induced luteolysis in control and Booroola Merinos. Proc. Aust. Soc. Reprod. Biol. 12, 50, Abstr.

Davis, G.H., Montgomery, G.W., Allison, A.J., Kelly, R.W. \& Bray, A.R. (1981) Fecundity in Booroola Merino sheep--further evidence of a major gene. Proc. Aust. Soc. Reprod. Biol. 13, 5, Abstr.

Davis, I., Brien, F.D., Findlay, J.K. \& Cumming, I.A. (1981) Interactions between dietary protein, ovulation rate and follicle stimulating hormone levels in the ewe. Anim. Reprod. Sci. 4, 19-28.

de Jong, F.H. (1979) Inhibin-fact or artifact. Molec. cell. Endocr. 13, 1-10.

de Jong, F.H. \& Sharpe, R.M. (1976) Evidence for inhibin-like activity in bovine follicular fluid. Nature, Lond. 263, 71-72.

Eddie, L. W., Baker, H.W.G., Higginson, R. \& Hudson, B. (1979) A bioassay for inhibin using pituitary cell cultures. J. Endocr. 81, 49-60.

Eddie, L.W., Baker, H.W.G., Burger, H.G., de Kretser, D.M., Higginson, R.E., Hudson, B., Lee, V.W.K. \& Niall, H.D. (1980) Suppression of FSH secretion in sheep by infusion of inhibin: dose-response relationship. Proc. 6th Int. Congr. Endocrinology, Melbourne, Abstract No. 550.

Erickson, G.F. \& Hsueh, A.J.W. (1978) Secretion of "inhibin" by rat granulosa cells in vitro. Endocrinology 103, 1960-1963.

Findlay, J.K. \& Bindon, B.M. (1976) Plasma FSH in Merino lambs selected for fecundity. J. Reprod. Fert. 46, 515-516.

Findlay, J.K. \& Cumming, I.A. (1977) The effect of unilateral ovariectomy on plasma gonadotropin levels, estrus and ovulation rate in sheep. Biol. Reprod. 17, 178-183.

Gidley-Baird, A.A. \& Bindon, B.M. (1976) A solid phase assay for luteinizing hormone in mouse plasma. Aust. J. biol. Sci. 29, 105-116.

Goding, J.R., Catt, K.J., Brown, J.M., Kaltenbach, C.C., Cumming, I.A. \& Mole, J.B. (1969) Radioimmunoassay for ovine luteinizing hormone. Secretion of luteinizing hormone during estrus and following estrogen administration in the sheep. Endocrinology 85, 133-142.

Goodman, R.L., Pickover, S.M. \& Karsch, F.J. (1981) Ovarian feedback control of follicle stimulating hormone in the ewe. Evidence for selective suppression. Endocrinology 108, 772-777.

Hermans, W.P., van Leeuwen, E.C.M., Debets, M.H.M. \& de Jong, F.H. (1980) Involvement of inhibin in the regulation of follicle stimulating hormone concentrations in prepubertal and adult male and female rats. Endocrinology 86, 79-82.
Hopkinson, C.R.N., Fritze, E., Chari, S., Sturm, G. \& Hirschhäuser, C. (1977) Interaction between testosterone and an inhibin preparation in male rat. Int. Res. Commun. Sys. Med. Sci. 5, 83.

Knight, T.W., Payne, E. \& Peterson, A.J. (1981) Effect of diet and live-weight on FSH and oestradiol concentrations in Romney ewes. Proc. Aust. Soc. Reprod. Biol. 13, 19, Abstr.

Lee, V.W.K., McMaster, J., Quigg, H., Findlay, J.K. \& Leversha, L. (1981) Ovarian and peripheral blood inhibin concentrations increase with gonadotropin treatment in immature rats. Endocrinology 108, 24032405.

Marder, M.L., Channing, C.P. \& Schwartz, N.B. (1977) Suppression of serum follicle stimulating hormone in intact and acutely ovariectomized rats by porcine follicular fluid. Endocrinology 101, 1639-1642.

Miller, K.F., Wesson, J.A. \& Ginther, O.J. (1981) Interaction of estradiol and a nonsteroidal follicular fluid substance in the regulation of gonadotropin secretion in the mare. Biol. Reprod. 24, 354-358.

O'Shea, T., Cummins, L.J., Lutjen, P. \& Bindon, B.M. (1980) Some factors affecting the response of ewes to injection of follicular fluid. Proc. Aust. Soc. Reprod. Biol. 12, 63, Abstr.

Peek, J.C. \& Watkins, W.B. (1980) Synergism between bovine seminal plasma extract and testosterone propionate in suppressing serum concentrations of gonadotropins in acutely castrated rats: a role for inhibin. Endocrinology 86, 349 355.

Peters, H. \& McNatty, K.P. (Eds) (1980) The Ovary. Granada Publ. Ltd, London.

Piper, L.R. \& Bindon, B.M. (1982) Genetic segregation for fecundity in Booroola Merino sheep. Proc. Wld Congr. Sheep Cattle Breed. (in press).

Sato, E., Miyamoto, H., Ishibashi, T. \& Iritani, A. (1978) Identification, purification and immunohistochemical detection of the inhibitor from porcine ovarian follicular fluid to compensatory ovarian hypertrophy in mice. J. Reprod. Fert. 54, 263-267.

Scott, R.S., Burger, H.G. \& Quigg, H. (1980) A simple and rapid in-vitro bioassay for inhibin. Endocrinology 107, 1536-1542.

Tsonis, C.G. \& Findlay, J.K. (1981) Aromatase activity, steroid content and atresia in ovine follicles. Proc. Endocr. Soc. Aust. 24, 75, Abstr.

Tsonis, C.G., Quigg, H.E., Lee, V.W.K., Leversha, L., Trounson, A.O. \& Findlay, J.K. (1981) Inhibin levels in individual sheep follicles. Proc. Aust. Soc. Reprod. Biol. 13, 33, Abstr.

Turner, H.N. (1978) Selection for reproductive rate in Australian Merino sheep: direct responses. Aust. J. agric. Res. 29, 327-350.

Welschen, R., Hermans, W.P., Dullaart, J. \& de Jong, F.H. (1977) Effects of an inhibin-like factor present in bovine and porcine follicular fluid on gonadotrophin levels in ovariectomized rats. J. Reprod. Fert. 50, 129-131.

Welschen, R., Hermans, W.P. \& de Jong, F.H. (1980) Possible involvement of inhibin in the interrelationship between numbers of antral follicles and peripheral FSH concentrations in female rats. $J$. Reprod. Fert. 60, 485-493. 